\title{
Adjustment of Mathematical Equations to Determine the Area Leaf of Cordia myxa L.
}

\author{
Michelle Teixeira Araujoㅁ, Ellen Maurício Faria1, Gabriel Linhares Cunha1, \\ Paloma de Moraes Nunes', Vinicius de Souza Oliveira², Karina Tiemi Hassuda dos Santos', \\ Omar Schmildt ${ }^{1}$, Antelmo Ralph Falqueto ${ }^{1}$, Mônica Maria Pereira Tognella ${ }^{1}$, \\ Edilson Romais Schmildt ${ }^{1}$
}

${ }^{1}$ Center North of Espírito Santo, Federal University of Espírito Santo, São Mateus, Espírito Santo, Brazil

${ }^{2}$ Center for Agricultural Sciences and Engineering, Federal University of Espírito Santo, Alegre, Espírito Santo, Brazil

Email: souzaoliveiravini@gmail.com

How to cite this paper: Araujo, M.T., Faria, E.M., Cunha, G.L., de Moraes Nunes, P., de Souza Oliveira, V., dos Santos, K.T.H., Schmildt, O., Falqueto, A.R., Tognella, M.M.P. and Schmildt, E.R. (2020) Adjustment of Mathematical Equations to Determine the Area Leaf of Cordia myxa L. Agricultural Sciences, 11, 609-616. https://doi.org/10.4236/as.2020.117038

Received: May 25, 2020

Accepted: July 5, 2020

Published: July 8, 2020

Copyright $\odot 2020$ by author(s) and Scientific Research Publishing Inc. This work is licensed under the Creative Commons Attribution International License (CC BY 4.0).

http://creativecommons.org/licenses/by/4.0/

\begin{abstract}
The objective of this study was to obtain mathematical equations through the leaf dimensions to estimate the area leaf of Cordia myxa L. 392 leaves of plants were collected, located in the municipality of São Mateus, North of the State of Espírito Santo, Brazil, 300 of which were used to adjust the equations and 92 for validation. Of all the leaves, the largest length $(L)$ and maximum width $(W)$ were measured, product of multiplying the length with the width $(L W)$ and the real leaf area $(R L A)$. Models equation first degree linear, quadratic and power were fitted, where $R L A$ was the dependent variable as a function of $L, W$ and $L W$ as an independent variable. All equations were validated according to appropriate criterion. Thus, the power model

$E L A=0.84(L W)^{0.9749}$, based on the product of multiplication of length with width $(L W)$ is the most suitable for estimating the leaf area of Cordia myxa L.
\end{abstract}

\section{Keywords}

Non-Destructive Method, Validated, Modeling

\section{Introduction}

Cordia myха L. is a species native to Asia, popularly known as Assyrian plum and belonging to the Boraginaceae family, widespread especially in the tropics and temperate regions of the world, an ecological characteristic present in Boraginaceae is the ability of many of its species to establish themselves in areas very disturbed, therefore being useful species for the reforestation of areas where the anthropic action is evident [1]. 
The measurement of the area leaf can be an important parameter in studies related to plant morphology, anatomy and ecophysiology, as it allows to obtain a fundamental indicator for understanding the plant's responses to environmental factors, since the leaves are the main organs responsible for photosynthetic process, its knowledge being able to estimate the loss of water through transpiration, in addition to the absorption and conversion of light energy into chemical energy [2] [3].

The determination of the area leaf can be carried out by direct or indirect, destructive or non-destructive methods. The direct methods are those that use measurements made directly on the leaves, where they often require the removal of the leaf or other structures, which may not be possible, due to the limited number of plants, in the experimental plot, in its turn the indirect methods are based on the known correlation between a measured variable and the leaf area, obtaining precise and easy mathematical equations, this being a non-destructive method and the measures can be taken on the plant, without the need to remove structures [4].

The use of mathematical equations to estimate leaf area has been reported for several plant species [5]-[11]. However, no literature is lack of studies that seek to model the area leaf for Cordia myxa L.

Thus, the objective of this study was to obtain mathematical equations and indicate the most appropriate for estimating the area leaf of Cordia myxa L. in a non-destructive way from the linear dimensions of the leaves.

\section{Material and Methods}

The study was carried out at the Federal University of Espírito Santo, Campus São Mateus, located in the North of the State of Espírito Santo, Brazil, with the following geographical coordinates: $18^{\circ} 40^{\prime} 36^{\prime \prime}$ south latitude and $39^{\circ} 51^{\prime} 35^{\prime \prime}$ longitude East. The climate of the region is characterized according to Köppen as tropical AW, with dry winter and rain during the summer [12].

The experiment was based on the collection of 392 leaves of Cordia myxa L. healthy and at different stages of development, in the four cardinal points, which did not present damage or attack from diseases or pests, as suggested by Oliveira et al. [6], soon the leaves were packed in plastic bags and quickly transported to the laboratory. In the laboratory, of each leaf, the largest length $(L)$ and the largest width $(W)$ of the leaf blade was determined using a ruler graduated in $\mathrm{cm}$ (Figure 1). The length was measured along the main midrib, which is the distance between the base of the leaf at the point of insertion of the petiole to its apex, and the width, considered in the middle part of the leaf. Subsequently, the real leaf area $(R L A)$ of each leaf was determined in $\mathrm{cm}^{2}$, with the aid of the Licor LI-3100 table meter. The product of multiplying the length with the width (LW in $\mathrm{cm}^{2}$ ) was also calculated. Descriptive statistics of the data were determined by obtaining the values of maximum, minimum, mean, amplitude, standard deviation $(S D)$ and coefficient of variation $(C V)$. 
L

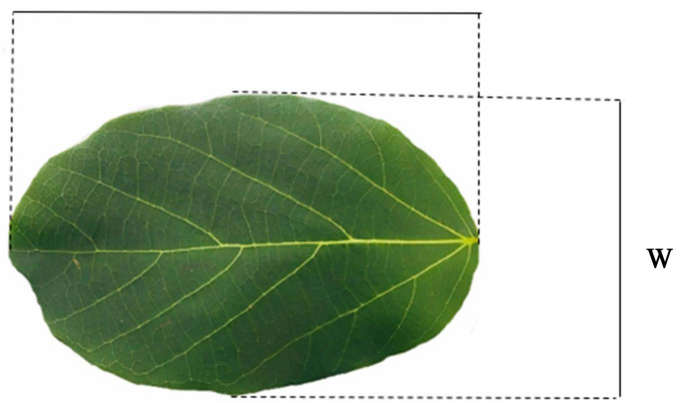

Figure 1. Representation of the length $(L)$ along the midrib and the maximum width $(W)$ of leaves of Cordia myxa L.

For the modeling, 300 leaves were used in which $R L A$ was defined with the dependent variable as a function of $L, W$ or $L W$ as independent variables, being tested the models first degree linear represented by $E L A=\hat{\beta}_{0}+\hat{\beta}_{1} x$, quadratic represented by $E L A=\hat{\beta}_{0}+\hat{\beta}_{1} x+\hat{\beta}_{2} x^{2}$ and power represented by $E L A=\hat{\beta}_{0} x^{\hat{\beta}_{1}}$, totaling nine equations and their respective coefficient of determination $\left(R^{2}\right)$.

For validation, the $L, W$ and $L W$ values of 92 leaves that were sampled for this purpose were replaced in the equations proposed in the modeling, thus obtaining the estimated leaf area $(A F E)$, in $\mathrm{cm}^{2}$. A simple linear equation $\left(E L A=\hat{\beta}_{0}+\hat{\beta}_{1} x\right)$ was thus adjusted, where ELA was used as a dependent variable as a function of RLA. The hypotheses $H_{0}: \beta_{0}=0$ versus $H_{a}: \beta_{0} \neq 0$ and $H_{0}: \beta_{1}=1$ versus $H_{a}: \beta_{1} \neq 1$ were tested, using the Student $\mathrm{t}$ test at $5 \%$ probability. The mean absolute error $(M A E)$, the root of the root mean square error (RMSE) and the Willmott $d$ index [13] were also determined for all equations estimated using expressions 1,2 and 3.

$$
\begin{gathered}
M A E=\frac{\sum_{i=1}^{n}|E L A-R L A|}{n} \\
R M S E=\sqrt{\frac{\sum_{i=1}^{n}(E L A-R L A)^{2}}{n}} \\
d=1-\left[\frac{\sum_{i=1}^{n}(E L A-R L A)^{2}}{\sum_{i=1}^{n}(|E L A-\overline{R L A}|+\mid R L A-\overline{R L A})^{2}}\right]
\end{gathered}
$$

where: $E L A$, are the estimated values of leaf area; $R L A$, are the real values of leaf area; $\overline{R L A}$ is the average of the real leaf area values; $n$, is the number of leaves sampled for validation, 92 in the present study.

The criterion for selecting the best models was based on linear coefficient $\left(\beta_{0}\right)$ is not different from zero, slope $\left(\beta_{1}\right)$ is not different from one, values of the mean absolute error $(M A E)$ and root mean square error (RMSE) closest to zero and Willmott's $d$ index [13] closest to one.

Statistical analyzes were performed with the aid of the R software [14], with scripts developed for the data package ExpDes.pt version 1.2 [15]. 


\section{Results and Discussion}

High variability of the sampled data was observed, verified by the high amplitude, with values above the average for all characteristics (Table 1), in addition, the values of the coefficient of variation ( $C V$ ) were higher than $25.30 \%$ for both the sample used for modeling as for the sample used for modeling, these values being considered high or very high [16]. This high variation was also found by several authors when studying mathematical models to estimate the leaf area of other species [7] [10] [11]. These data point out that in the sample collected there are leaves of different stages of development and consequently of different sizes, which is a fundamental characteristic in the study of modeling, since the adjusted equations can later be used throughout the crop cycle [5] [8].

The nine equations adjusted to estimate the leaf area of Cordia myxa L. through their linear dimensions can be seen in Table 2. Note that there was a better relationship between the real leaf area $(A F R)$ and the product of multiplying the length with the width $(L W)$ in the three models studied with coefficient of determination $\left(R^{2}\right)$ greater than 0.98 , showing that more than $98 \%$ of the area leaf of Cordia myxa L. leaves can be explained by $L W$. This better relationship can be explained since the length and width are different measures and when combined they become more appropriate than when used individually [17]. However, we must not pay attention only to the high values of $R^{2}$ when choosing the best equation, because its use, without any other validation criteria, may imply an erroneous estimate of the leaf area [18].

When analyzing the coefficients of the nine adjusted equations (Table 3), five equations showed results not significantly different from zero for the linear coefficient $\left(\beta_{0}\right)$ and not significantly different from one for the slope $\left(\beta_{1}\right)$. This finding suggests that for these equations, as $1 \mathrm{~cm}^{2}$ in the real leaf area increases, the equation will add $1 \mathrm{~cm}^{2}$ in the estimated leaf area and when the real leaf area is $0 \mathrm{~cm}^{2}$, the model will estimate a leaf area of $0 \mathrm{~cm}^{2}$ [9]. However, despite the

Table 1. Descriptive statistics with value minimum, maximum, mean, amplitude, standard deviation $(S D)$ and coefficient of variation $(C V)$ of the variables: length $(L)$; width $(W)$; product of the length and width $(L W)$ and real leaf area $(R L A)$ of leaves of Cordia myxa L.

\begin{tabular}{cccccccc}
\hline Variable & Unit & Minimum & Max & Average & Amplitude & $S D$ & $C V$ \\
\hline \multicolumn{7}{c}{ 300 leaves were used for modeling } \\
$W$ & $\mathrm{~cm}$ & 2.20 & 18.50 & 12.21 & 16.30 & 3.49 & 28.57 \\
$W$ & $\mathrm{~cm}$ & 1.50 & 13.40 & 8.40 & 11.90 & 2.33 & 27.72 \\
$L W$ & $\mathrm{~cm}^{2}$ & 3.30 & 227.94 & 109.93 & 224.64 & 51.92 & 47.23 \\
$R L A$ & $\mathrm{~cm}^{2}$ & 2.15 & 165.75 & 81.81 & 163.60 & 38.13 & 46.61 \\
& & & 92 leaves for validation & & & \\
$L$ & $\mathrm{~cm}$ & 4.00 & 18.80 & 10.82 & 14.80 & 3.06 & 28.28 \\
$W$ & $\mathrm{~cm}$ & 2.70 & 12.40 & 7.34 & 9.70 & 1.86 & 25.31 \\
$L W$ & $\mathrm{~cm}^{2}$ & 10.80 & 208.68 & 84.36 & 197.88 & 42.31 & 50.15 \\
$R L A$ & $\mathrm{~cm}^{2}$ & 6.90 & 156.27 & 62.95 & 149.37 & 30.88 & 49.05 \\
\hline
\end{tabular}


Table 2. Equation with linear adjustment of first degree, quadratic and power and its respective coefficient of determination $\left(R^{2}\right)$ using the real leaf area $(R L A)$ as dependent variable, in function of length $(L)$, width $(W)$, product of length with width $(L W)$ of leaves of Cordia myxa L.

\begin{tabular}{ccc}
\hline Model & Equation & $R^{2}$ \\
\hline Linear & $E L A=-44.5504+10.3528(L)$ & 0.9562 \\
Linear & $E L A=-51.0881+15.8153(W)$ & 0.9453 \\
Linear & $E L A=1.530010+0.730324(L W)$ & 0.9980 \\
Quadratic & $E L A=-6.18991+2.52336(L)+0.35508(L)^{2}$ & 0.9794 \\
Quadratic & $E L A=18.40043-6.56575(W)+0.59243(W)^{2}$ & 0.9760 \\
Quadratic & $E L A=0.5416317+0.7537996(L W)+0.0001077(L W)^{2}$ & 0.9980 \\
Power & $E L A=0.9202(L)^{1.7718}$ & 0.9787 \\
Power & $E L A=1.7727(W)^{1.7772}$ & 0.9760 \\
Power & $E L A=0.84(L W)^{0.9749}$ & 0.9980 \\
\hline
\end{tabular}

Table 3. Linear coefficient $\left(\beta_{0}\right)$, slope $\left(\beta_{1}\right)$ and determination coefficient $\left(R^{2}\right)$, obtained from equations with first line linear adjustment between real leaf area $(R L A)$ and estimated leaf area $(E L A)$ of linear equations of first degree, quadratic and power for the independent variables length $(L)$, width $(W)$ and product of length and width $(L W)$, besides, mean absolute error (MAE), root mean square error (RMSE) and Willmott $d$ index of leaves of Cordia myxa L. used for validation.

\begin{tabular}{cccccccc}
\hline Model & Variable & $\beta_{0}^{(1)}$ & $\beta_{1^{(2)}}$ & $R^{2}$ & $M A E$ & $R M S E$ & $d$ \\
\hline Linear & $L$ & $0.1353^{\mathrm{ns}}$ & $0.9315^{*}$ & 0.9125 & 8.3482 & 10.4170 & 0.9718 \\
Linear & $W$ & $-2.5234^{\mathrm{ns}}$ & $1.0071^{\mathrm{ns}}$ & 0.9184 & 7.0333 & 9.0634 & 0.9770 \\
Linear & $L W$ & $0.0443^{\mathrm{ns}}$ & $0.9963^{\mathrm{ns}}$ & 0.9938 & 1.8806 & 2.4475 & 0.9984 \\
Quadratic & $L$ & $2.2029^{\mathrm{ns}}$ & $0.9213^{*}$ & 0.9216 & 7.2919 & 9.4981 & 0.9769 \\
Quadratic & $W$ & $-3.2847^{\mathrm{ns}}$ & $1.0389^{\mathrm{ns}}$ & 0.9324 & 6.0627 & 8.1441 & 0.9810 \\
Quadratic & $L W$ & $0.2068^{\mathrm{ns}}$ & $0.9933^{\mathrm{ns}}$ & 0.9938 & 1.8823 & 2.4448 & 0.9984 \\
Power & $L$ & $2.1869^{\mathrm{ns}}$ & $0.9218^{*}$ & 0.9215 & 7.2941 & 9.4895 & 0.9769 \\
Power & $W$ & $-5.3833^{*}$ & $1.0684^{*}$ & 0.9339 & 6.2172 & 8.2288 & 0.9801 \\
Power & $L W$ & $0.0796^{\mathrm{ns}}$ & $0.9948^{\mathrm{ns}}$ & 0.9938 & 1.8785 & 2.4438 & 0.9984 \\
\hline
\end{tabular}

(1) ${ }^{\text {ns}} V$ alue of $\beta_{0}$ does not differ from zero by Student's t-test, at a level of $5 \%$; (1) ${ }^{*}$ Value of $\beta_{0}$ differs from zero by Student's t-test, at a level of 5\%; (2) ns Value of $\beta_{1}$ does not differ from one, by Student's t-test, at a level of 5\%; (2) *Value of $\beta_{1}$ differs from one, by Student's t-test, at a level of 5\%.

fact that five equations have no significant effect for $\beta_{0}$ and $\beta_{1}$, the power model equations adjusted from the product of the length with the width proved to be more effective in determining the leaf area of Cordia myxa L. because it indicates less error in the estimation verified by the values of the mean absolute error $(M A E)$ and root mean square error (RMSE) closer to zero, besides, of index values $\mathrm{d}$ closer to one. 


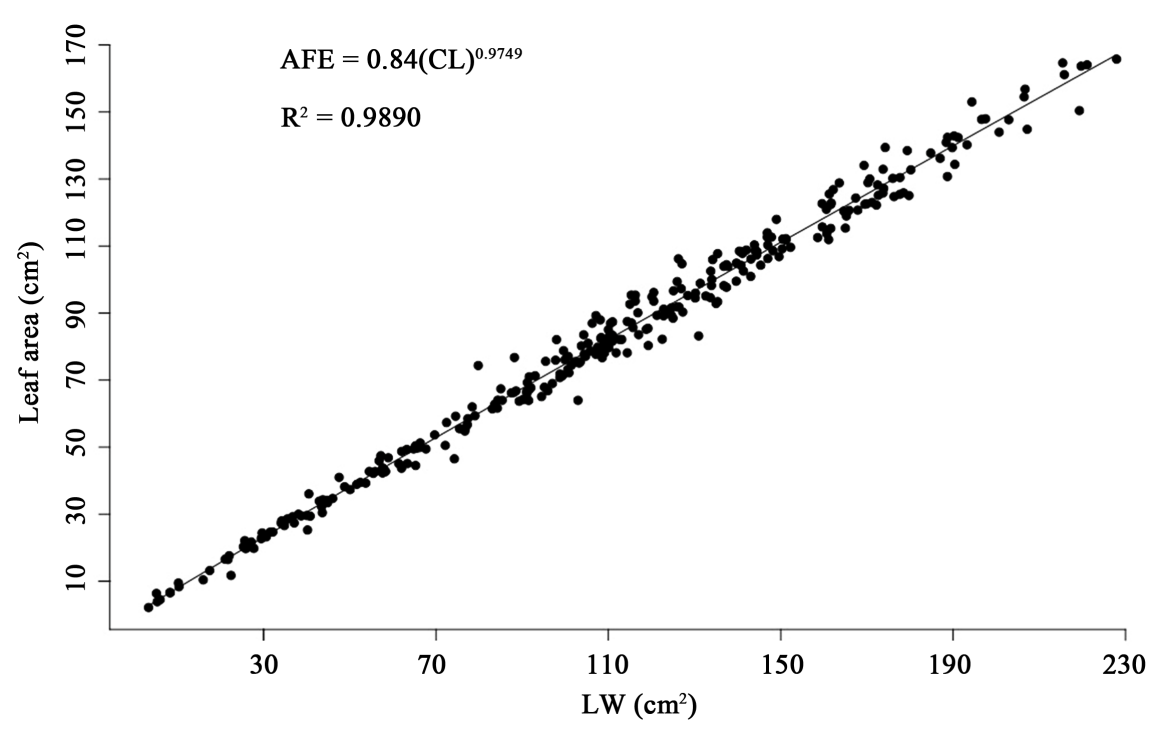

Figure 2. Adjusted equation of power model and its coefficient of determination $\left(R^{2}\right)$, using the real leaf area $(R L A)$ as dependent variable, as a function of the product of length and width $(L W)$ of leaves of Cordia myxa L.

The equations adjusted with only one measurement of the leaf surface ( $L$ or $W$ ) are easier to use in practice [8]. However, this type of equation is less accurate and may require different adjustments throughout the vegetative cycle of the plants, thus requiring different equations for the different stages of development [19]. Thus, the results presented here show us that the equation $E L A=0.84(L W)^{0.9749}$ whose behavior can be seen in Figure 2 is the most accurate in estimating the leaf area of Cordia myxa L. This equation was chosen because it presents the best results when submitted to appropriate validation methods [20].

\section{Conclusion}

The power model equation represented by $E L A=0.84(L W)^{0.9749}$ adjusted from the product of the length with the width is the most accurate in estimating the leaf area of Cordia myxa L. and can be used without the easy way without the need to destroy the leaves.

\section{Acknowledgements}

CNPq, CAPES and FAPES for financial support.

\section{Conflicts of Interest}

The authors declare no conflicts of interest regarding the publication of this paper.

\section{References}

[1] Barroso, I.C.E., Oliveira, F. and Ciarelli, D.M. (2009) Morfologia da unidade de 
dispersão e germinação de Cordia sellowiana Cham e Cordia myxa L. Bragantia, 68, 241-249. https://doi.org/10.1590/S0006-87052009000100026

[2] Favarin, J.L., Dourado Neto, D., García, A.G., Nova, N.A.V. and Favirin, M.G.G.V. (2002) Equações para estimativa do índice de área foliar do cafeeiro. Pesquisa agropecuária brasileira, 37, 769-773. https://doi.org/10.1590/S0100-204X2002000600005

[3] Lopes, M.C., Andrade, I., Pedroso, V. and Martins, S. (2004) Modelos empírico para a estimativa de área foliar da videira na casta Jaen. Ciência e Tecnologia Vitivinicultura, 19, 61-75.

[4] Benincasa, M.M.P. (1988) Análise do crescimento de plantas: Noções básicas. FUNEP, Jaboticabal, $42 \mathrm{p}$.

[5] Schmildt, E.R., Schmildt, O., Alexandre, R.S., Fernandes, A.A. and Czepak, M.P. (2016) Modelos alométricos na determinação da área foliar de Bauhinia monandra Kurz. Comunicata Scientiae, 7, 415-419. https://doi.org/10.14295/cs.v7i3.1095

[6] Oliveira, P.S., Silva, W., Costa, A.A.M., Schmildt, E.R. and Vitória, E.L. (2017) Leaf Area Estimation in Litchi by Means of Allometric Relationships. Revista Brasileira de Fruticultura, 39, 1-6. https://doi.org/10.1590/0100-29452017403

[7] Cargnelutti Filho, A., Toebe, M., Burin, C., Neu, I.M.M. and Alves, B.M. (2018) Número de folhas para modelar a área foliar de mucuna cinza por dimensões foliares. Revista de Ciências Agroveterinárias, 17, 571-578. https://doi.org/10.5965/223811711732018571

[8] Oliveira, V.S., Carvalho, C.F.M., França, J.M., Pinto, F.B., Santos, K.T.H., Santos, J.S.H., Santos, G.P., Pinheiro, A.P.B., Schmildt, O., Czepak, M.P., Arantes, S.D., Alexandre, R.S., Amaral, J.A.T., Vitória, E.L. and Schmildt, E.R. (2019a). Alometric Model for Estimation of Leaf Area of Garcinia brasiliensis Mart. through Non-Destructive Method. Journal of Agricultural Science, 11, 154-161. https://doi.org/10.5539/jas.v11n10p154

[9] Oliveira, V.S., Pinheiro, A.P.B., Silva, J.V.G., Jardim, A.S., Fernandes, A.A., Schmildt, O., Arantes, S.D., Posse, R.P. and Schmildt, E.R. (2019) Uso de imagens digitalizadas para elaboração de equações que estime a área foliar de mudas de $E u$ genia uniflora L. International Journal of Development Research, 9, 31062-31064.

[10] Pinheiro, A.P.B., Oliveira, V.S., Santos, K.T.H., Santos, J.S.H., Santos, G.P., Silva, J.V.G., Jardim, A.S., Longue, L.L., Nunes, S.F., Azeredo, A.L.R., Pires, F.R., Fernandes, A.A., Schmildt, O., Czepak, M.P. and Schmildt, E.R. (2019) Estimation Leaf Area by Composite Leaves of Canavalia rosea Seedlings through Linear Dimensions from Last Leaflet. Journal of Agricultural Science, 11, 299-308. https://doi.org/10.5539/jas.v11n9p299

[11] Santos, J.S.H., Santos, K.T.H., Oliveira, V.S., Santos, G.P., Menezes, L.F.T., Czepak, M.P., Falqueto, A.R., Aoyama, E.M., Schmildt, O. and Schmildt, E.R. (2020) Regression Models for Prediction of Leaf Area in Purple Ipe [Tabebuia impetiginosa (Mart.)]. Australian Journal of Crop Science, 12, 654-659. https://doi.org/10.21475/ajcs.20.14.04.p2291

[12] Alvares, C.A., Stape, J.L., Sentelhas, P.C., Gonçalves, J.L.M. and Sparovek, G. (2014) Köppen's Climate Classification Map for Brazil. Meteorologische Zeitschrift, 22, 711-728. https://doi.org/10.1127/0941-2948/2013/0507

[13] Willmott, C.J. (1981) On the Validation of Models. Physical Geography, 2, 184-194. https://doi.org/10.1080/02723646.1981.10642213

[14] R Core Team (2020) R: A Language and Environment for Statistical Computing. R 
Foundation for Statistical Computing, Vienna.

[15] Ferreira, E.B., Cavalcanti, P.P. and Nogueira, D.A. (2018) Package "ExpDes.pt”.

[16] Pimentel-Gomes, F. (2009) Curso de estatística experimental. 15th Edition, Fealq, Piracicaba, $451 \mathrm{p}$.

[17] Lavanhole, D.F., Oliveira, P.S., Vitória, E.L. and Aoyama, E.M. (2018) Estimativa de área foliar por meio de relações alométricas em Aechmea blanchetiana (Baker) L. B. SM sob distintas condições de luminosidade. Iheringia: Série Botânica, 73, 363-373. https://doi.org/10.21826/2446-8231201873313

[18] Antunes, W.C., Pompelli, M.F., Carretero, D.M. and Damatta, F.M. (2008) Allometric Models for Non-Destructive Leaf Area Estimation in Coffee (Coffea arabica and Coffea canephora). Annals of Applied Biology, 153, 33-40. https://doi.org/10.1111/j.1744-7348.2008.00235.x

[19] Montero, F.J., Juan, J.A., Cuesta, A. and Brasa, A. (2000) Non Destructive Methods to Estimate Leaf Area in Vitis vinifera L. HortScience, 35, 696-698. https://doi.org/10.21273/HORTSCI.35.4.696

[20] Fascella, G., Darwich, S. and Rouphael, Y. (2013) Validation of a Leaf Area Prediction Model Proposed for Rose. Chilean Journal of Agricultural Research, 73, 73-76. https://doi.org/10.4067/S0718-58392013000100011 